\title{
A novel pathway of cGMP
}

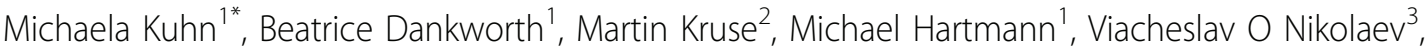 \\ Katharina Völker ${ }^{1}$, Birgit Gaßner ${ }^{1}$, Robert Feil ${ }^{4}$, Marc Freichel ${ }^{5}$, Olaf Pongs ${ }^{2}$, Michael Klaiber ${ }^{1}$ \\ From 5th International Conference on cGMP: Generators, Effectors and Therapeutic Implications \\ Halle, Germany. 24-26 June 2011
}

\section{Background}

Cardiac atrial natriuretic peptide (ANP) regulates arterial blood pressure, moderates cardiomyocyte growth, and stimulates angiogenesis and metabolism. ANP binds to the transmembrane guanylyl cyclase (GC) receptor, GCA to exert its diverse functions. This involves a cGMPdependent signaling pathway preventing pathological $\left[\mathrm{Ca}^{2+}\right]_{\mathrm{i}}$ raises in myocytes. In chronic cardiac hypertrophy, however, ANP levels are markedly increased and GC-A/cGMP responses to ANP are blunted due to receptor desensitization.

\section{Results}

Here we show that in this situation ANP binding to GC-A stimulates a novel cGMP-independent signaling pathway in cardiac myocytes, resulting in pathologically elevated intracellular $\mathrm{Ca}^{2+}$ levels $\left(\left[\mathrm{Ca}^{2+}{ }_{\mathrm{i}}\right]\right)$. This pathway involves the activation of TRPC3/C6 $\mathrm{Ca}^{2+}$ channels (transient receptor potential canonical channel 3/6) by GC-A which forms a stable complex with TRPC3/C6 channels. Our results indicate that the resulting TRPC3/C6-mediated $\mathrm{Ca}^{2+}$ entry then stimulates Calmodulin Kinase II (CaMKII) to phosphorylate L-type $\mathrm{Ca}^{2+}$ channels leading to increased L-type $\mathrm{Ca}^{2+}$ channel mediated $\mathrm{Ca}^{2+}$ current and a rise in intracellular $\mathrm{Ca}^{2+}$ levels.

\section{Conclusion}

These observations reveal a dual role of the ANP/GC-A signaling pathway in the regulation of cardiac myocyte $\mathrm{Ca}^{2+}{ }_{\mathrm{i}}$-homeostasis. Under physiological conditions, activation of a cGMP-dependent pathway moderates the $\mathrm{Ca}^{2+}{ }_{\mathrm{i}}$-enhancing action of hypertrophic factors such as Angiotensin II. By contrast, a cGMP-independent pathway predominates under pathophysiological conditions, when GC-A is desensitized by high ANP levels. The

\footnotetext{
* Correspondence: michaela.kuhn@mail.uni-wuerzburg.de

${ }^{1}$ Institute of Physiology, University of Würzburg, Germany

Full list of author information is available at the end of the article
}

concomitant rise in $\left[\mathrm{Ca}^{2+}{ }_{\mathrm{i}}\right]$ is likely to increase the propensity to cardiac hypertrophy and arrhythmias.

\section{Author details}

${ }^{1}$ Institute of Physiology, University of Würzburg, Germany. ${ }^{2}$ Institut für Neurale Signalverarbeitung, Universität Hamburg, Germany. ${ }^{3}$ Institute of Pharmacology, University of Würzburg, Germany. Interfakultäres Institut für Biochemie, Universität Tübingen, Germany. ${ }^{5}$ Experimentelle und Klinische Pharmakologie und Toxikologie, Universität des Saarlandes, Hamburg, Germany.

Published: 1 August 2011

doi:10.1186/1471-2210-11-S1-028

Cite this article as: Kuhn et al:: A novel pathway of CGMP. BMC Pharmacology 2011 11(Suppl 1):O28.

\section{Submit your next manuscript to BioMed Central and take full advantage of:}

- Convenient online submission

- Thorough peer review

- No space constraints or color figure charges

- Immediate publication on acceptance

- Inclusion in PubMed, CAS, Scopus and Google Scholar

- Research which is freely available for redistribution

\section{() Biomed Central}

\section{Biomed Central}

(C) 2011 Kuhn et al; licensee BioMed Central Ltd. This is an open access article distributed under the terms of the Creative Commons Attribution License (http://creativecommons.org/licenses/by/2.0), which permits unrestricted use, distribution, and reproduction in any medium, provided the original work is properly cited. 